\title{
Genetic Diversity of Potato Based on Random Amplified Polymorphic DNA and Simple Sequence Repeat Marker
}

DOI: $10.18196 /$ pt.2020.114.54-62

\author{
Sapto Nugroho $\mathrm{Hadi}^{1 *}$, Siti Nurchasanah ${ }^{2}$ \\ ${ }^{1}$ Agroecology Laboratory, Faculty of Agriculture, Jenderal Soedirman University, \\ Jl. Dr. Soeparno No. 61 Purwokerto, Central Java, Indonesia 53123 \\ 2Plant Breeding and Biotechnology Laboratory, Faculty of Agriculture, Jenderal Soedirman University, \\ Jl. Dr. Soeparno No. 61 Purwokerto, Central Java, Indonesia 53123 \\ *Corresponding autors, email: snhadi@gmail.com
}

\begin{abstract}
Various potato clones are cultivated by farmers in Banjarnegara and Wonosobo, Central Java, Indonesia such as MZ, NH1, NH2, Vega, Gareta, Granola, Bliss, Merah (Red Potato), Ungu (Purple Potato), Klon_17 (K17), Local Dieng, Margahayu, and X. This encourages the importance of genetic diversity and genetic similarities. This study aimed to analyze genetic diversity and genetic similarities between 13 accessions of potatoes based on seven Random Amplified Polymorphic DNA (RAPD) primers and nine pairs of Simple Sequence Repeat Marker (SSR) primers. The results showed that RAPD and SSR primers could be used to analyze genetic diversity and genetic similarities of 13 potatoes accessions from Banjarnegara and Wonosobo. The PLP value was $80.9 \%$ in the RAPD primer and $65.41 \%$ in the SSR primer. Four RAPD primers were informative based on PIC value: OPG 08, OPM 19, OPP 13, and OPX 04. Three SSR primer were informative: STM 2005, RGH- SSR 8, and Stl 035. Genetic similarities presented by Phylogenetic tree analysis resulted in two main clusters. The first cluster consisted of Granola, MZ, Ungu (Purple potato), Merah (Red Potato), Local Dieng, Margahayu, Gareta, Vega, NH2, NH1, Klon_17 (K17), and Bliss. The second cluster consisted of X. Granola and MZ having a high genetic similarity with a genetic distance of 0.07 and 0.132. Meanwhile, K17 and $X$ had a low genetic similarity with a genetic distance of 0.31 and 0.987 .
\end{abstract}

Keywords: Banjarnegara, RAPD, Solanum tuberosum L., SSR, Wonosobo

ABSTRAK

Berbagai klon kentang dibudidayakan oleh petani di Banjarnegara dan Wonosobo, Jawa Tengah, Indonesia seperti MZ, NH1, NH2, Vega, Gareta, Granola, Bliss, Red (Red Potato), Ungu (Ungu Potato), Klon_17 (K17), Lokal Dieng, Margahayu, dan X. Pentingnya keragaman genetik dan kemiripan genetik. Penelitian ini bertujuan untuk menganalisis keragaman genetik dan kesamaan genetik antara 13 aksesi kentang berdasarkan tujuh primer Random Amplified Polymorphic DNA (RAPD) dan sembilan pasang Simple Sequence Repeat Marker(SSR) primer. Hasil penelitian menunjukkan bahwa primer RAPD dan SSR dapat digunakan untuk keragaman genetik dan kesamaan genetik dari 13 aksesi kentang dari Banjarnegara dan Wonosobo. Nilai PLP adalah 80,9\% pada RAPD primer dan 65,41\% pada SSR primer. Empat RAPD utama bersifat informatif berdasarkan nilai PIC: OPG 08, OPM 19, OPP 13, dan OPX 04. Tiga SSR primer bersifat informatif: STM 2005, RGH - SSR 8, dan Stl 035. Kesamaan genetik yang disajikan oleh analisis pohon Phylogenetic menghasilkan dua kelompok utama. Kelompok pertama terdiri atas Granola, MZ, Ungu kentang, Kentang Merah, Lokal Dieng, Margahayu, Gareta, Vega, NH2, NH1, Klon_17 (K17), dan Bliss. Kelompok kedua terdiri atas X. Granola dan MZ memiliki kesamaan genetik yang tinggi dengan jarak genetik 0,07 dan 0,1 32. K17 dan X memiliki kesamaan genetik yang rendah dengan jarak genetik 0,31 dan 0,987.

Kata Kunci: Banjarnegara, RAPD, Solanum tuberosum L., SSR, Wonosobo

\section{INTRODUCTION}

Potatoes are an important horticultural commodity in Indonesia. Nevertheless, the production of potato in Indonesia from 2014 to 2017 continued to decline. According to Central Bureau of Statistics data (2017), potato production in 2014 reached $1,347,728$ tons, decreasing to $1,219,277$ tons in 2015 and 1,164,738 in 2017. The decline in the potato production also occurred in Central Java, which is one of the potato production centers in Indonesia. Data from the Indonesian Ministry of Agriculture (2017) stated that the number of potato production in Central Java in 2014 reached 292,214 tons, decreasing to 278,552 tons in 2015, 272,976 tons in 2016, and 269,476 tons in 2017. The percentage decreasing in the potato production in Central Java reached minus 1.28\%, lower than the percentage decline in potato production in Indonesia which reached minus 9.54\% (Ministry of Agriculture, 2017).

In terms of productivity, the number of potato productivity in Indonesia is relatively low. Potato productivity in Indonesia ranges from 15.4 to 
18.23 tons/hectare (ha) (Ministry of Agriculture, 2017). Meanwhile, potato productivity in European countries such as Belgium reaches 44.3 tons/ ha or the Netherlands reaches 42.2 tons/ha. The value of potato productivity in Indonesia in the range of 2013 to 2016 had increased, but in the range of 2016 to 2017 it came to a decrease. Meanwhile, the value of potato productivity in Central Java in the range of 2013 to 2017 continued to increase (Table 1). The percentage of potato productivity in Central Java upgraded to of $20.17 \%$, in contrast to the percentage of potato productivity in Indonesia which declined up to minus $15.49 \%$. Nevertheless, in general the potato productivity figures in Central Java from 2013 to 2016 were still below the potato productivity in Indonesia nationally.

Table 1. Potato productivity figures in Indonesia and Central Java for the period of 2013-2017

\begin{tabular}{lrrrrr}
\hline \multirow{2}{*}{\begin{tabular}{c} 
Potato Productivity (ton/ha) \\
\cline { 2 - 6 } \multicolumn{1}{c}{}
\end{tabular}} & $\mathbf{5}$ & \multicolumn{5}{c}{ Year } \\
\hline Indonesia & 16.02 & 17.67 & 18.20 & 18.23 & 15.40 \\
Central Java & 15.51 & 16.44 & 17.18 & 18.25 & 21.94 \\
\hline
\end{tabular}

(Ministry of Agriculture, 2017)

The decline in potato production and productivity in Indonesia is caused by a number of factors. Some of them are harvested areas which are dropping in numbers and the use of low-quality potato seeds for cultivation. In 2014 the potato harvested area reached 76,291 hectares. However, potato harvested area declined in 2015 (66,983 hectares) and 2016 (66,450 hectares) (Central Bureau of Statistics, 2017). The second factor is due to the low quality of potato seeds used by farmers. Some farmers still use potato seeds from potato cultivation in the previous year. The use of certified superior seeds among potato farmers is still low. One of the reasons is that the existing seed supply system has not run optimally, so it cannot meet the needs of farmers for certified seeds (Fauziyah, 2018). In addition, the price of certified potato seeds is relatively more expensive than potato seeds made by farmers themselves (Sayaka and Hestina, 2011).

To increase potato production and productivity, the development of superior seeds is very important. Besides its long process and stages, developing superior potato also requires basic information such as genetic diversity and similarities among existing potato cultivars. The aim is to find out the superior character of each potato cultivar so that it can be used in potato plant breeding programs.

Analysis of potato genetic diversity and similarities can be carried out with several approaches, such as morphology and molecular. Both approaches make use of a marker owned and become a characteristic of potato. Approach using morphological markers has weaknesses such as long-time requirement, relatively expensive, influence from the environment, and limited diversity (Zulfahmi, 2013). To overcome such disadvantages, the molecular markers come into use.

This technique is based on the use of deoxyribonucleic acid molecules as molecular markers. Molecular markers can directly mark specific genes and can eliminate the influence of environmental factors. Analysis of potato genetic diversity and similarities through the molecular markers approach is divided into several techniques. Two of them are Random Amplified Polymorphic DNA (RAPD) and Simple Sequence Repeat (SSR) or microsatellite.

RAPD is based on random genomic DNA amplification using the oligonucleotide primer (Kumar et al., 2009). The superiority of the RAPD technique, which does not need DNA sequence information, requires a small quantity of DNA sample (about 5 - $50 \mathrm{ng}$ per reaction); the primer is commercially available, and does not require radioactive (Leksono, 2011; Kumar et al., 2009). SSR is a sequence of 1 to 10 repeat nucleotides tandemly as a composer of the genome repeating 
area (Vieira et al., 2016). SSR is most widely used as a molecular marker because it has various advantages, such as specific (Zulfahmi, 2013), highly informative, codominant, high reproducibility, largely abundant, multi-allele and non-radioactive genomes (Kumar et al. , 2009; Miah et al., 2013).

In Banjarnegara and Wonosobo Regency, Central Java, various potato clones have been cultivated by local farmers, some of which are MZ, NH1, NH2, Vega, Gareta, Granola, Bliss, Red Potato, Purple Potato, Klon_17 (K17), Local Dieng, Margahayu, and X. Generally, clones are the result of captive potato farmers in the region and no genetic diversity and similarities are known.

This study aimed to analyse genetic diversity and genetic similarities between 13 accessions of potatoes cultivated in Banjarnegara and Wonosobo district, Central Java Province, Indonesia based on seven RAPD primers and nine SSR primers.

\section{MATERIALS AND METHODS}

The materials used were potato leaf samples from Banjarnegara and Wonosobo Regency, Central Java Province, Indonesia (Table 2) and RAPD and SSR oligonucleotides primers (Table 3) (1st base).

Table 2. Potato Accession and the Origin

\begin{tabular}{lll}
\hline No & Accession & Origin \\
\hline 1. & MZ & Batur, Banjarnegara \\
2. & NH1 & Batur, Banjarnegara \\
3. & NH2 & Batur, Banjarnegara \\
4. & Vega & Batur, Banjarnegara \\
5. & Gareta & Batur, Banjarnegara \\
6. & Granola & Batur, Banjarnegara \\
7. & Blis & Batur, Banjarnegara \\
8. & Merah (Red Potato) & Dieng Kulon, Banjarnegara \\
9. & Ungu (Purple Potato) & Dieng Kulon, Banjarnegara \\
10. & Klon 17 (K17) & Dieng Wetan, Wonosobo \\
11. & Local Dieng & Dieng Wetan, Wonosobo \\
12. & Margahayu & Dieng Wetan, Wonosobo \\
13. & X & Dieng Wetan, Wonosobo \\
\hline
\end{tabular}

\section{DNA Extraction}

DNA extraction used a modified CTAB method (Doyle \& Doyle, 1987). Potato leaf samples were placed in a mortar and then added with liquid nitrogen and crushed until smooth. Powder samples dissolved with CTAB mixture were then incubated for one hour. The sample suspension was added with $500 \mu \mathrm{L}$ of chloroform (Merck) mixture: alcohol isoamyl (24:1) and then precipitated with 32 $\mu \mathrm{L}$ of ammonium acetate (Merck) and $233.28 \mu \mathrm{L}$ of isopropanol (Merck) and incubated overnight at $60 \mathrm{oC}$. The pellets were added with $500 \mu \mathrm{L}$ of $70 \%$ ethanol (Merck), $500 \mu \mathrm{L}$ of $96 \%$ cold ethanol (Merck) and $200 \mu \mathrm{L}$ of ammonium acetate (Merck). After drying, the sample was added with $2 \mu \mathrm{L}$ of RNAse $(2.5 \mu \mathrm{g} / \mathrm{mL})$ (Geneaid) and $50 \mu \mathrm{L}$ of nuclease-free water (Promega). The samples were then ready for next analysis.

\section{DNA Amplification by Polymerase Chain Reaction}

The RAPD reactions were performed in a final volume of $25 \mu \mathrm{L}$. The mixture contained $1 \mu \mathrm{L}$ of DNA $(50 \mathrm{ng} / \mu \mathrm{L}), 3 \mu \mathrm{L}$ of RAPD primer $(10 \mu \mathrm{M})$ (1st base), $5 \mu \mathrm{L}$ of $5 \mathrm{x}$ My Taq Red Reaction Buffer (Bioline), $0.5 \mu \mathrm{L}$ of My Taq HS Red DNA Polymerase (Bioline), 15,5 $\mu \mathrm{L}$ of Nuclease-Free Water (Promega). This method refers to Yaycili and Alikamanoglu (2012). PCR program for RAPD primers was presented in Table 4. PCR products were electrophoresed on $1 \%$ of agarose gel, about 45 minutes at 75 volts.

The SSR reactions were carried out with $25 \mu \mathrm{L}$ final volume. The mixture contained $1 \mu \mathrm{L}$ of DNA $(50 \mathrm{ng} / \mu \mathrm{L}), 0.75 \mu \mathrm{L}$ of forward and reverse primer $(10 \mu \mathrm{M})(1$ st base), $5 \mu \mathrm{L}$ of $5 \mathrm{x}$ My Taq Red Reaction Buffer (Bioline), $0.5 \mu \mathrm{L}$ of My Taq HS Red DNA Polymerase (Bioline), and $17 \mu \mathrm{L}$ of Nuclease-Free Water (Promega). The PCR program for SSR primers is presented in Table 5. PCR products were electrophoresed on $3 \%$ of agarose gel about 55 minutes at 100 volts. 


\section{Data Analysis}

PCR results were converted to binary data. Number 1 was if the DNA band appeared and 0 was if no DNA band appeared. The data were used to determine the value of Polymorphic percentage (PLP) and Polymorphic Information Content (PIC), and to reconstruct phylogenetic trees represented in genetic similitaries. The formula to know the PLP and PIC was as follow:

$$
\text { PLP }=\frac{\sum(L P)}{\sum(L P)+\sum(L M)}
$$

Note :

$\Sigma(\mathrm{LP}) \quad$ : sum of polymorphic locus

$\Sigma(\mathrm{LM}) \quad$ : sum ofmonomorphic locus
$\mathrm{PIC}=1-\Sigma \mathrm{Pij}^{2}$

Note:

$\mathrm{Pi}$ : frequency of $\mathrm{j}$ pattern were obtained by primer i

Phylogenetic trees reconstruction based on Unweighted Pair Group Method with Arithmetic (UPGMA) and Maximum Composite Likelihood used software Mega in 6.0 version (Tamura et al., 2013).

\section{RESULTS AND DISCUSSION}

\section{RAPD Analysis}

The DNA isolated from the potato leaf sample was amplified with the RAPD primer to determine its profile so that it could be used for genetic diver-

Table 3. RAPD and SSR oligonucleotide primers

\begin{tabular}{|c|c|c|c|}
\hline No & Name & Sequence & References \\
\hline 1 & OPG 08 & TCACGTCCAC & Rocha et al., 2010 \\
\hline 2 & OPG 13 & CTC TCC GCC A & Rocha et al., 2010 \\
\hline 3 & OPJ 13 & CCA CAC TAC C & Rocha et al., 2010 \\
\hline 4 & OPM 19 & GTCCGTACTG & Rocha et al., 2010 \\
\hline 5 & OPN 02 & ACCAGGGGCA & Rocha et al., 2010 \\
\hline 6 & OPP 13 & GGAGTGCCTC & Rocha et al., 2010 \\
\hline 7 & OPX 04 & CCG CTA CCG A & Rocha et al., 2010 \\
\hline 8 & STM 1052 & $\begin{array}{l}\mathrm{F}: \text { CAATTTCGTTTTTTCATGTGACAC } \\
\mathrm{R}: \text { ATGGCGTAATTTGATTTAATACGT }\end{array}$ & Ghislain et al.,2004 \\
\hline 9 & STM 2005 & $\begin{array}{l}\mathrm{F}: \text { TTTAAGTTCTCAGTTCTGCAG } \\
\mathrm{R}: \text { GTCATAACCTTTACCATTGCTGGG }\end{array}$ & Milbourne et al., 1997 \\
\hline 10 & STM 3012 & $\begin{array}{l}\mathrm{F}: \text { AAT TCT ATC CTC ATC TCTA } \\
\mathrm{R}: \text { CAA CTC AAA CCA GAA GGC AAA }\end{array}$ & Ghislain et al.,2004 \\
\hline 11 & STM 3015 & $\begin{array}{l}\mathrm{F} \text { : AGC AAT AAA GTC AAC ACT CCA TCA } \\
\text { R :AAT GAA TTA GGG GGA GGT GTG }\end{array}$ & Ghislain et al. 2004 \\
\hline 12 & RGH-SSR 8 & $\begin{array}{l}\mathrm{F}: \text { GAATTTTCTCCACTGGCAGC } \\
\mathrm{R}: \text { TCCAAGGAAACAAAACTTGACC }\end{array}$ & Bakker et al., 2011 \\
\hline 13 & RGH-SSR 48 & $\begin{array}{l}\mathrm{F}: \text { AAT TCT TTGAAA TTG GCC CC } \\
\mathrm{R}: \text { CAC ACC CAACAATCT TTCCC }\end{array}$ & Bakker et al., 2011 \\
\hline 14 & РОТ 083 & $\begin{array}{l}\text { F : GGGACATCACAGTCT } \\
\mathrm{R}: \mathrm{GGTGCTCCTATTGGTG}\end{array}$ & Salimi et al., 2016 \\
\hline 15 & St1053 & $\begin{array}{l}\text { F : TCAGACCGGGTTCGATGG } \\
\mathrm{R}: \text { CGGCTTGAATCATTGCCCA }\end{array}$ & Feingold et al., 2005 \\
\hline 16 & Stl055 & $\begin{array}{l}\mathrm{F}: \text { CCGTTGATGGGATTGCACA } \\
\mathrm{R}: \text { TGATATTAACCATGGCAGCAGC }\end{array}$ & Feingold et al., 2005 \\
\hline
\end{tabular}

Note: 1-7: RAPD primer, 8-16: SSR primer; F: forward primer, R: reverse primer 
Table 4. PCR program for RAPD

\begin{tabular}{lccc}
\hline Step & $\begin{array}{c}\text { Temperature } \\
\left({ }^{\circ} \mathrm{C}\right)\end{array}$ & $\begin{array}{c}\text { Time } \\
\text { (second) }\end{array}$ & $\begin{array}{c}\text { Cycle } \\
\text { (times) }\end{array}$ \\
\hline Pre-Denaturation & 95 & 60 & 1 \\
Denaturation & 94 & 10 & 34 \\
Annealing & 36 & 30 & 34 \\
Extension & 72 & 30 & 34 \\
Final Extension & 72 & 420 & 1 \\
\hline
\end{tabular}

(Williams et al., 1990; Rocha et al., 2010)

Table 5. PCR program for SSR

\begin{tabular}{lccc}
\hline Step & $\begin{array}{c}\text { Temperature } \\
\left({ }^{\circ} \mathrm{C}\right)\end{array}$ & $\begin{array}{c}\text { Time } \\
(\text { second) }\end{array}$ & $\begin{array}{c}\text { Cycle } \\
\text { (times) }\end{array}$ \\
\hline Pre-Denaturation & 95 & 180 & 1 \\
Denaturation & 95 & 60 & 30 \\
Annealing & 57 & 30 & 30 \\
Extension & 72 & 60 & 30 \\
Final Extension & 72 & 600 & 1 \\
\hline
\end{tabular}

(Salimi et al.,2016)

sity and similarities analysis. Examples of RAPD analysis with primer OPG 08 primers are presented in Figure 1.

Of the seven RAPD primers used, all primers showed polymorphisms with the appearance of DNA bands with different sizes from a range of $250 \mathrm{bp}$ to $1600 \mathrm{bp}$. The example was the results of RAPD analysis with primer OPG 08 (Figure 1). There were five DNA bands for NH2, Local Dieng and Ungu samples with a size of about $250 \mathrm{bp}$, 400 bp, 550 bp, 750 bp, and 1000 bp, four DNA bands for Red sample with a size of about $375 \mathrm{bp}$, $550 \mathrm{bp}, 750 \mathrm{bp}$, and $1000 \mathrm{bp}$, four DNA bands for NH1, Margahayu, and MZ sample with a size of about 400 bp, 550 bp, 750 bp, and 1000 bp, three DNA bands for Gareta and X sample with a size of about $400 \mathrm{bp}, 750 \mathrm{bp}$, and $1000 \mathrm{bp}$, one DNA band for Vega sample with a size of about $400 \mathrm{bp}$, three DNA bands for Granola sample with a size of about $250 \mathrm{bp}, 400 \mathrm{bp}$, and $550 \mathrm{bp}$, two DNA bands for K17 sample with a size of about $375 \mathrm{bp}$, $550 \mathrm{bp}$, and $1000 \mathrm{bp}$, and bands for Bliss sample with a size of about $375 \mathrm{bp}$ and $550 \mathrm{bp}$.
The results of polymorphism using RAPD primers were produced in accordance with the results of analysis of several similar primers conducted by Rocha et al. (2010) on 16 commercial potato cultivars in Brazil.

\section{SSR Analysis}

Isolated DNA from potato leaf samples were also amplified with SSR primers for analysis of genetic diversity and similarities. Examples of the results of SSR analysis with primer STM 1052 was presented in Figure 2. From the nine pairs of SSR primers used, all primers showed polymorphisms with the appearance of DNA bands with different sizes from a range of $150 \mathrm{bp}$ to $200 \mathrm{bp}$. The example was the results of the SSR analysis by primer STM 1052 (Figure 2a); there was one DNA band appearing at a length of about $200 \mathrm{bp}$ for NH2 and Vega samples, two DNA bands at a length of about 150 bp and 200 bp for Merah, NH1, X, Margahayu, Local Dieng, Granola, Ungu, MZ, and K17 samples,

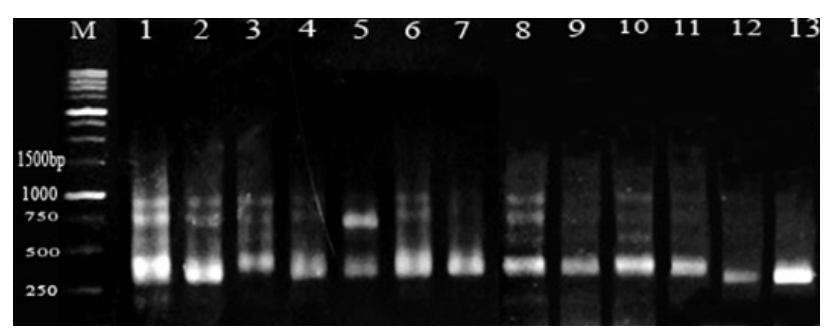

Figure 1. Results of RAPD analysis of 13 potato accessions using primer OPG 08. M: 1 kb DNA Ladder, 1: NH2, 2: Merah, 3: NH1, 4: Gareta, 5: X, 6: Margahayu, 7: Vega, 8: Local Dieng, 9: Granola, 10: Ungu, 11: MZ, 12: K17, 13: Bliss. There are polymorphisms in the sample analyzed

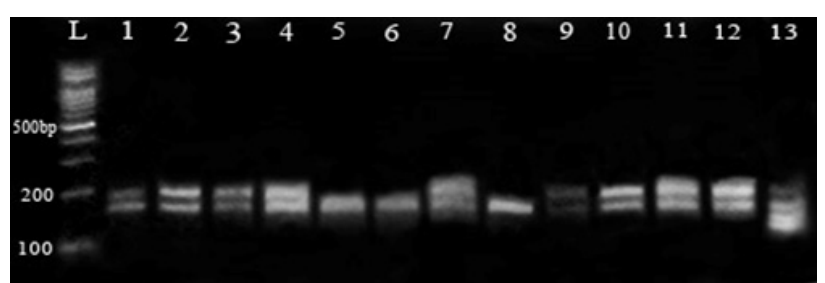

Figure 2. Results of SSR analysis with primer STM 1052. M: 100 bp DNA Ladder, 1: NH2, 2: Merah, 3: NH1, 4: Gareta, 5: X, 6: Margahayu, 7: Vega, 8: Local Dieng, 9: Granola, 10: Ungu, 11: MZ, 12: K17, 13: Bliss. There were polymorphisms in the sample analyzed 
and two DNA bands appeared at a length of about $175 \mathrm{bp}$ and $200 \mathrm{bp}$ for Gareta samples.

\section{Genetic Diversity Based on PLP and PIC Value}

Based on Table 6 , genetic diversity analysis in 13 accessions of potatoes using 7 RAPD primers could detect 67 alleles with a mean of 9.57 alleles per primer. The mean of alleles detected in this study was lower than that of Collares et al. (2004) which yielded 10.75 alleles per primer on detection in 29 accessions of potatoes using 4 RAPD primers. However, it was higher when compared with the results of Hoque et al., (2013) which yielded 4.87 alleles per primer. A total of 55 alleles were polymorphic or $80.9 \%$ of the total allele. These results did not differ significantly from the results of Onamu et al. (2016) which characterized 35 accessions of potatoes with 19 RAPD primers. However, this result was still lower than Yasmin et al. (2006) study which analyzed 6 potato cultivars using 3 RAPD primers with PLP value of $94.29 \%$. The highest PLP value was obtained by OPG 08 and OPM 19, which was $100 \%$, while the lowest was by OPN 02 in 42.9\%. PLP information was essential to determine the level of genetic variation in a population. The higher the PLP value, the higher the level of variation would be (Kawengian et al., 2016). Polymorphic bands were obtained from differences in PCR band size. Each primer produced a different polymorphic pattern, because each primer produced the DNA band at different base sizes (Sinaga et al., 2017).

For PIC values, seven RAPD primers yielded values ranging from 0.31 to 0.78 with an average of 0.54 . The PIC values were lower when compared with the results of Rocha et al., (2010) resulting in a mean of PIC values of 0.9 with the same primer in the analysis of 16 potato cultivars. This difference is thought to be due to the low repetition of RAPD analysis (Jones et al., 1997), thus allowing for variations in results.
According to Nugroho et al., (2015), PIC values are values that inform the level of polymorphism of a molecular marker. PIC also illustrates the level of efficiency of a marker to distinguish genotypes. The PIC value of $>0.5$ indicated informative marker which was useful for distinguishing genotypes, while the PIC value of $<0.5$ was less informative or less efficient in distinguishing genotypes. Based on these criteria, 4 RAPD primers were classified as informative, i.e., OPG 08, OPM 19, OPP 13, and OPX 04, while the other 3 primers were classified as less informative, i.e., OPG 13, OPJ 13 and OPN 02.

According to Table 7, nine SSR primers succeeded in amplifying 28 alleles with a mean of 3.11 alleles per primer. 19 alleles showed a polymorphic band pattern with a mean of $65.41 \%$. StI053 and StI055 showed the highest PLP value, which

Table 6. PLP dan PIC of RAPD

\begin{tabular}{lcccc}
\hline Primer & $\begin{array}{c}\text { Sum of locus } \\
\text { (alel) }\end{array}$ & $\begin{array}{c}\text { Polymorphic } \\
\text { locus }\end{array}$ & $\begin{array}{c}\text { PLP } \\
(\%)\end{array}$ & PIC \\
\hline OPG 08 & 6 & 6 & 100 & 0,60 \\
OPG 13 & 11 & 7 & 63,6 & 0,31 \\
OPJ 13 & 7 & 6 & 85,7 & 0,46 \\
OPM 19 & 12 & 12 & 100 & 0,78 \\
OPN 02 & 7 & 3 & 42,9 & 0,42 \\
OPP 13 & 13 & 12 & 92,3 & 0,68 \\
OPX 04 & 11 & 9 & 81,8 & 0,54 \\
\hline Total & 67 & 55 & & \\
\hline Average (mean) & 9,57 & 7,85 & 80,90 & 0,54 \\
\hline
\end{tabular}

Table 7. PLP dan PIC of SSR

\begin{tabular}{lcccc}
\hline Primer & $\begin{array}{c}\text { Sum of locus } \\
\text { (alel) }\end{array}$ & $\begin{array}{c}\text { Polymorphic } \\
\text { locus }\end{array}$ & $\begin{array}{c}\text { PLP } \\
(\%)\end{array}$ & PIC \\
\hline OPG 08 & 3 & 2 & 67,0 & 0,49 \\
OPG 13 & 3 & 2 & 67,0 & 0,77 \\
OPJ 13 & 2 & 1 & 50,0 & 0,26 \\
OPM 19 & 2 & 1 & 50,0 & 0,47 \\
OPN 02 & 7 & 5 & 71,4 & 0,68 \\
OPP 13 & 3 & 1 & 33,3 & 0,09 \\
OPX 04 & 2 & 1 & 50,0 & 0,47 \\
StI053 & 3 & 3 & 100, & 0,69 \\
StI055 & 3 & 3 & 100, & 0,32 \\
\hline Total & 28 & 19 & & \\
\hline Average (mean) & 3,11 & 2,11 & 65,41 & 0,47 \\
\hline
\end{tabular}


was $100 \%$, while RGH-SSR 48 was the lowest at $33.3 \%$. This result was lower than Favoretto et al., (2011) which yielded 46 polymorphic alleles with a mean of 4.6 per primer using 10 SSR primers. This result was also lower than Hubert et al. (2015) that reported 42 detectable alleles and 37 alleles or $88 \%$ polymorphic on identification of 11 Indian potatoes using 10 SSR primers.

Table 6 also showed the PIC values generated from SSR primers ranging from 0.26 to 0.77 with a mean of 0.47. The lowest value was STM 3012 and the highest one was STM 2005. This result was different from the result of Nugroho et al. (2015) which resulted in PIC values ranging from 0.41 to 0.76 with a mean of 0.59 in the analysis of 14 accessions of potatoes using 14 SSR primers. However, these results were no different from those of Salimi et al. (2016) which resulted in a mean of PIC of 0.42 . Of the 9 SSR primers, 3 primers were informative because they showed the PIC value of > 0.5 in STM 2005, RGH-SSR 8, and StI035. Meanwhile, 6 primer PIC values were less informative because the values were $<0.5$ as in STM 1052, STM 3012, STM 3015, RGH-SSR 48, POT 083, and StI055.

\section{Genetic similarities}

According to Figure 3, analysis of genetic similarities using RAPD primers in 13 potato accessions based on the UPGMA method found that the closest genetic distance was found in the Granola and MZ accessions, which was 0.07. Based on the Maximum Composite Likelihood method, the closest genetic distance for Granola and MZ was also produced with a genetic distance of 0.132 (Figure 4). This indicates that these two accessions had a high genetic similarity. It is known that Granola and MZ were produced from the same elders, Granola (Ministry of Agriculture, 2014). These molecular data were supported by morphological data that there was a similarity between the

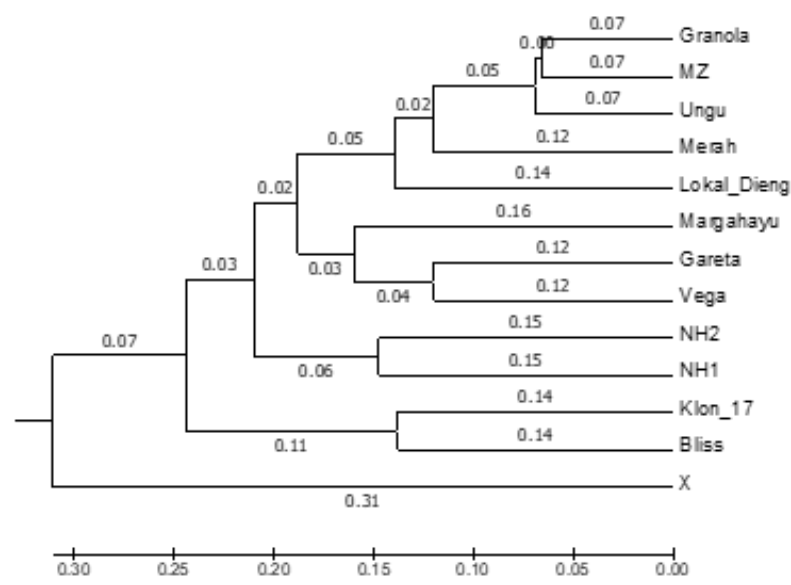

Figure 3. Dendrograms representing the genetic similarities obtained based on RAPD and SSR markers in 13 potato cultivars generated by UPGMA

morphology of Granola and MZ such as large oval leaves, feathers on the leaves, purple flowers, yellow bulb skins, and yellowish fleshy bulbs.

Another interesting thing is in the Ungu accession (purple potatoes). This potato is the result of breeding performed by local potato seed breeders from various existing superior varieties. Based on information from local farmers, one of the elders of purple potatoes was the $\mathrm{MZ}$ variety. The results of genetic diversity analysis using the RAPD primer supported this information. Purple potatoes and MZ had high genetic similarities. From the dendrogram presented in Figure 3, the genetic distance data of purple potato and $\mathrm{MZ}$ was 0.07 , equal to the genetic distance between Granola and MZ. Although morphologically the color of tuber between them was different. MZ has bright yellow tuber, while Ungu has purplish tuber.

Referring to Figure 3, it is also produced that the farthest genetic distance was found in potato accessions of $\mathrm{K} 17$ and $\mathrm{X}$. Both genetic distances were 0.31 . The data were also supported by analysis based on the Maximum Composite Likelihood method which also produced the farthest genetic distance for $\mathrm{K} 17$ and $\mathrm{X}$, with genetic distance of 0.987 (Figure 4). This indicates that both accessions shared low genetic similarities. Based on personal discussions with potato seed breeders in 


\begin{tabular}{|c|c|c|c|c|c|c|c|c|c|c|c|c|c|}
\hline & 1 & 2 & 3 & 4 & 5 & 6 & 7 & 8 & 9 & 10 & 11 & 12 & 13 \\
\hline \multicolumn{14}{|l|}{ 1. $\mathrm{NH} 2$} \\
\hline 2. $\mathrm{NH} 1$ & 0.295 & & & & & & & & & & & & \\
\hline 3. Merah & 0.357 & 0.295 & & & & & & & & & & & \\
\hline 4. Gareta & 0.403 & 0.482 & 0.315 & & & & & & & & & & \\
\hline 5. $\mathrm{X}$ & 0.651 & 0.612 & 0.576 & 0.403 & & & & & & & & & \\
\hline 6. Margahayu & 0.790 & 0.403 & 0.295 & 0.380 & 0.428 & & & & & & & & \\
\hline 7. Vega & 0.454 & 0.336 & 0.315 & 0.240 & 0.651 & 0.258 & & & & & & & \\
\hline 8. Lokal_Dieng & 0.336 & 0.403 & 0.336 & 0.482 & 0.482 & 0.357 & 0.482 & & & & & & \\
\hline 9. Granola & 0.454 & 0.380 & 0.240 & 0.403 & 0.576 & 0.380 & 0.315 & 0.258 & & & & & \\
\hline 10. Ungu & 0.428 & 0.454 & 0.223 & 0.380 & 0.543 & 0.454 & 0.380 & 0.207 & 0.132 & & & & \\
\hline 11. $M Z$ & 0.380 & 0.357 & 0.258 & 0.428 & 0.693 & 0.357 & 0.295 & 0.315 & 0.132 & 0.146 & & & \\
\hline 12. Klon_17 & 0.357 & 0.482 & 0.454 & 0.576 & 0.987 & 0.543 & 0.512 & 0.380 & 0.357 & 0.380 & 0.223 & & \\
\hline 13. Bliss & 0.403 & 0.482 & 0.651 & 0.576 & 0.848 & 0.693 & 0.512 & 0.790 & 0.454 & 0.543 & 0.390 & 0.276 & \\
\hline
\end{tabular}

Figure 4. Genetic distance using the Maximum Composite Likelihood method. The closest distance was 0.132 between accession of Granola and MZ, while the farthest distance was 0.987 between accession $\mathrm{K} 17$ and $\mathrm{X}$

the research location, accession X is not yet known Purple Potato, Red Potato, and Local Dieng. The as which parent. The morphological character of second cluster consisted of X. Granola and MZ accession $\mathrm{X}$ was also different compared to other which had a high genetic similarity with a genetic accessions cultivated in Batur Banjarnegara and distance of 0.07 and 0.132 respectively, while K17 Dieng Wonosobo.

Based on the results of the phylogenetic tree by RAPD dan SSR analysis presented in Figure 3, potato accession from Banjarnegara and Wonosobo were classified into two main clusters. The first cluster consisted of Granol, MZ, Ungu (Purple potato), Merah (Red potato), Local Dieng, Margahayu, Gareta, Vega, NH2, NH1, Klon_17 (K17), and Bliss. The second cluster consisted of X. Potato accessions in the same cluster which had greater genetic similarity than different clusters.

\section{CONCLUSIONS}

The results showed that RAPD and SSR primers could be used to analyze genetic diversity and genetic similarities in 13 potatoes accessions from Banjarnegara and Wonosobo. The PLP value was $80.9 \%$ for RAPD and $65.41 \%$ for SSR. Four RAPD primers were informative: OPG 08, OPM 19, OPP 13, and OPX 04. Three SSR primers were also informative: STM 2005, RGH- SSR 8, and STI 035. Phylogenetic tree analysis yielded two main clusters. The first cluster consisted of Bliss, Grannola, Vega, MZ, Margahayu, Gareta, NH1, NH2, and $\mathrm{X}$ had a low genetic similarity with a genetic distance of 0.31 and 0.987 respectively.

\section{ACKNOWLEDGMENT}

Acknowledgment is conveyed to LPPM UNSOED for the support of research funding and other parties assisting in all stages of research and writing.

\section{REFERENCES}

Bakker, E., Borm, T., Prins, P., Van der Vossen, G., Uenk, G., Arens, A., de Boer, J., Van Eck, H., Muskens, M., Vossen, J., Van der Linden, G., Van Ham, R., KleinLankhorst, R., Visser, R., Smant, G., Bakker, J., \& Goverse, A. (2011). A genome-wide genetic map of NB-LRR disease resistance loci in potato. Theor. Appl. Genet, 123:493-508.

Central Bureau of Statistics. (2017). Vegetable Crop Production. https://www.bps.go.id/site/resultTab. Accessed on August 3, 2018.

Collares, E. A. S., Choer, E., \& da Silva Pereira, A. (2004). Characterization of potato genotypes using molecular markers. Pesq. agropec. Bras, 39 (9) : 871-878.

Doyle, J.J. \& Doyle, J.L. (1987) A Rapid DNA Isolation Procedure for Small Quantities of Fresh Leaf Tissue. Phytochemical Bulletin, 19: 11-15.

Fauziyah, S. (2018). Faktor-faktor yang mempengaruhi keputusan petani dalam menggunakan benih kentang bersertifikat. Studi kasus Kecamatan Cikajang, Kabupaten Garut, Jawa Barat. Skripsi. Institut Pertanian Bogor, Bogor.

Favoretto, P., Veasey, E. A., \& de Melo, P. C. T. (2011). Molecular 
characterization of potato cultivars using SSR markers. Horticultura Brasileira, 29: 542-547.

S. Feingold, Lloyd, J., Norero, N., \& Bonierbale, J.M. (2005). Lorenzen Mapping and characterization of new EST-derived microsatellites for potato (Solanum tuberosum L.). Theor Appl Genet, 111: 456-466.

Ghislain M., Spooner, D.M., Rodriguez, F., Villamon, F., Nunez, J., Vasquez, C., Waugh, R., \& Bonierbale, M. (2004). Selection of highly informative and user-friendly microsatellites (SSRs) for genotyping of cultivated potato. Theor Appl Gennet, 108: 881-890.

Hoque, M.E., Huq, H., \& Moon, N.J. (2013). Molecular diversity analysis in potato (Solanum tuberosum L.) through RAPD markers. SAARC J. Agri, 11(2): 95-102.

Hubert,G. Y. J., Gupta, P.H., Patel, N.J., Shah, A.K., Acharya, R.R, Talati, J.G. (2015). Molecular Characterization of Indian Potato (Solanum tuberosum L.) Varieties for Cold-Induced Sweetening Using SSR Markers. Journal of Plant Sciences, 3(4): 191-196.

Jones, C.J., Edwards, K.J., Castaglione, S., Winfield, M.O., Sala, F., van deWiel, C., Bredemeijer, G., Vosman, B., Matthes, M., Daly, A., Brettschneider, R., Bettini, P., Buiatti, M., Maestri, E., Malcevschi, A., Marmiroli, N., Aert, R., Volckaert, G., Rueda, J., Linacero, R., Vazquez, A., \& Karp, A. (1997). Reproducibility testing of RAPD, AFLP and SSR markers in plants by a network of European laboratories. Molecular Breeding, 3: 381-390.

Kawengian, Y. B., Lengkong, E. \& Mandang, J. (2016). Keragaman Genetik Beberapa Varietas Kentang (Solanum tuberosum L.) Berdasarkan Penanda Random Amplified Polimorphic DNA (RAPD). Jurusan Budidaya Fakultas Pertanian Universitas Sam Ratulangi Manado.

Kumar, U., Joshi, A. K., Kumar, S., Chand, R., \& Roder, M.S. (2009). Mapping of resistance to spot blotch disease caused by Bipolaris sorokiniana in spring wheat. Theor Appl Genet, 118:783-792

Leksono, A. S. (2011). Keanekaragaman Hayati. UB Press, Malang.

Miah, G., Rafii, M.Y., Ismail, M.R., Puteh, A.B., Rahim, H.A., Islam, Kh.N. \& Latif, M.A. (2013). A review of microsatellite markers and their applications in rice breeding programs to improve blast disease resistance. International Journal of Molecular Science, 14: 22499-22528.

Milbourne, B.D., Meyer, R., Bradshaw, J.E., Baird, E., Bonar, N., \& Provan, J. (1997). Comparison of PCR-based marker systems for the analysis of genetic relationship in cultivated potato. Mol Breed, 3: 127-136.

Ministry of Agriculture. (2014). Berita Resmi PVT Tedjo MZ. No. Publikasi :004/BR/PVL/02/2014. Available at: pvtpp.setjen. pertanian.go.id/cms/wp.../ 04/4.-Banjarnegara-Kentang-TedjoMZ.pdf

Ministry of Agriculture. (2017). Potato productivity by province, 2013-2017. http://www.pertanian.go.id/Data5tahun/HortiATAP2017(.pdf)/Produktivitas\%20Kentang.pdf. Accessed on February 6th, 2019.
Ministry of Agriculture. (2017). Potato Harvest Area by Province, 2013-2017. http://www.pertanian.go.id/Data5tahun/HortiATAP2017(.pdf)/L.\%20Panen\%20Kentang.pdf. Accessed on February 6th, 2019.

Ministry of Agriculture. (2017). Potato Production by Province, 2013-2017. http://www.pertanian.go.id/Data5tahun/HortiATAP2017(.pdf)/Produksi\%20Kentang.pdf. Accessed on February 6th, 2019.

Nugroho, K., Reflinur, Lestari, P., Rosdianti, I., Terryana, R.T., Kusmana, \& Tasma, I.M. (2015). Keragaman genetika empat belas aksesi kentang (Solanum tuberosum L. berdasarkan marka SSR dan STS. Jurnal AgroBiogen, 11(2):41-48.

Onamu, R., Legari, J., Rodríguez, J.L., Sahagùn, J. \& Pèrez, J. (2016). Molecular characterization of potato (Solanum tuberosum L.) genotypes using random amplified polymorphic DNA (RAPD) and inter simple sequence repeat (ISSR) markers. African Journal of Biotechnology, 15 (22) : 1015 -1025.

Rocha, E. M., Paiva, L.V., de Carvalho, H.H. \& Guimaraes, C.T. (2010). Molecular characterization and genetic diversity of potato cultivars using SSR and RAPD markers. Crop Breeding and Applied Biotechnology, 10: 204-210.

Salimi, H., Bahar, M., Mirlohi, A. \& Talebi, M. (2016). Assessment of the genetic diversity among potato cultivars from different geographical areas using the genomic and EST microsatellites. Iran Journal Biotech, 14(4): 270-277.

Sayaka, B. \& Hestina, J. (2011). Constraints in Adopting Certified Seed in Potato Farming. Forum Penelitian Agroekonomi, 29(1): 27-41

Sinaga, A., Putri, L. A. P. \& Bangun, M.K. (2017). Analisis pola pita andaliman (Zanthoxylum Acanthopodium D.C) berdasarkan primer OPD 03, OPD 20, OPC 07, OPM 20, OPN 09. Jurnal Agroekoteknologi FP USU, 5(1) : 55-64.

Tamura, K., Stecher, G., Peterson, D., Filipski, A. \& Kumar, S. (2013). MEGA6: Molecular Evolutionary Genetics Analysis Version 6.0. Mol. Biol. Evol., 30(12): 2725-2729

Vieira, M.L.C., Santini, L., Diniz, A.L. \& Munhoz Carla de Freitas. (2016). Microsatellite markers: what they mean and why they are so useful. Genetics and Molecular Biology, 39 (3): 312-328

Williams, J. G. K., Kubelik, A.R., Livak, K.J., Rafalski, J.A. \& Tingey, S.V. (1990). DNA polymorphisms amplified by arbitrary primers are useful as genetic markers. NucleicAcids Research, 18 (22): 6531-6535.

Yasmin, S., Islam, S., Khondoker, Nasirrudin \& Alam, S. (2006). Molecular characterization of potato germplasm by Random Amplified Polymorphic DNA markers. Biotechnology, 5 (1): 27 -31.

Yaycili, 0., \& Alikamanoğlu, S. (2012). Induction of salt-tolerant potato (Solanum tuberosum L.) mutants with gamma irradiation and characterization of genetic variations via RAPD-PCR analysis. Turk Journal Biol., 36: 405-412.

Zulfahmi. (2013). Penanda DNA untuk analisis genetik tanaman. Jurnal Agroteknologi, 3 (2): 41-52. 